Pacific Northwest

NATIONAL LABORATORY

\title{
Simulation of Columbia River Floods in the Hanford Reach
}

\section{January 2017}

SR Waichler JA Serkowski
WA Perkins

MC Richmond 


\section{DISCLAIMER}

This report was prepared as an account of work sponsored by an agency of the United States Government. Neither the United States Government nor any agency thereof, nor Battelle Memorial Institute, nor any of their employees, makes any warranty, express or implied, or assumes any legal liability or responsibility for the accuracy, completeness, or usefulness of any information, apparatus, product, or process disclosed, or represents that its use would not infringe privately owned rights. Reference herein to any specific commercial product, process, or service by trade name, trademark, manufacturer, or otherwise does not necessarily constitute or imply its endorsement, recommendation, or favoring by the United States Government or any agency thereof, or Battelle Memorial Institute. The views and opinions of authors expressed herein do not necessarily state or reflect those of the United States Government or any agency thereof.

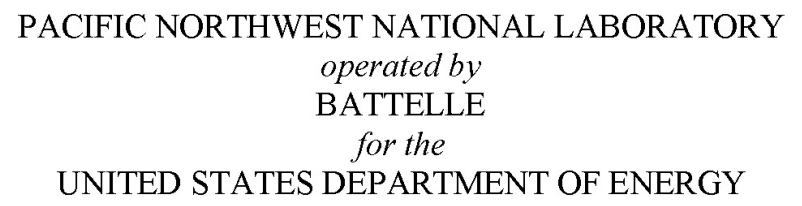

under Contract DE-AC05-76RL01830

Printed in the United States of America

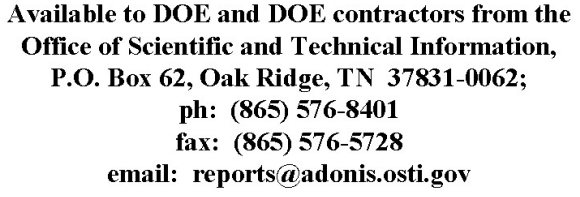

email: reports@adonis.osti.gov

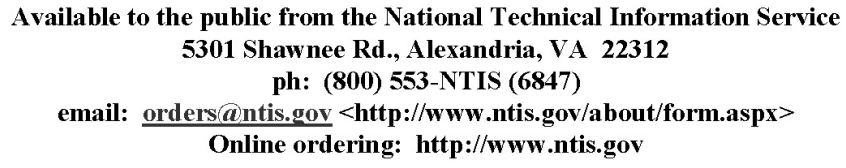




\section{Simulation of Columbia River Floods in the Hanford Reach}

SR Waichler

JA Serkowski
WA Perkins

MC Richmond

January 2017

Prepared for

Mission Support Alliance and U.S. Department of Energy under Contract DE-AC05-76RL01830

Pacific Northwest National Laboratory

Richland, Washington 99352 


\section{Summary}

Columbia River water elevations and flows in the Hanford Reach affect the environment and facilities along the shoreline, including movement of contaminants in groundwater, fish habitat, and infrastructure subject to flooding. This report describes the hydraulic simulation of hypothetical flood flows using the best available topographic and bathymetric data for the Hanford Reach and the Modular Aquatic Simulation System in 1 Dimension (MASS1) hydrodynamic model. The MASS1 model of the Hanford Reach was previously calibrated to field measurements of water surface elevations. The current model setup can be used for other studies of flow, water levels, and temperature in the Reach.

The existing MASS1 channel geometry and roughness and other model configuration inputs for the Hanford Reach were used for this study, and previous calibration and validation results for the model are reprinted here for reference. The flood flows for this study were simulated by setting constant flow rates obtained from the U.S. Army Corps of Engineers (USACE) for the Columbia, Snake, and Yakima Rivers, and a constant water level at McNary Dam, and then running the model to steady state. The discharge levels simulated were all low-probability events; for example, a 100-year flood is one that would occur on average every 100 years, or put another way, in any given year there is a $1 \%$ chance that a discharge of that level or higher will occur. The simulated floods and their corresponding Columbia River discharges were 100-year (445,000 cfs), 500-year (520,000 cfs), and the USACE-defined Standard Project Flood ( $960,000 \mathrm{cfs})$. The resulting water levels from the steady-state floods can be viewed as "worst case" outcomes for the respective discharge levels.

The MASS1 output for water surface elevations was converted to the North American Vertical Datum of 1988 and projected across the channel and land surface to enable mapping of the floodplain for each scenario. Floodplain maps show that for the 100-year and 500-year discharge levels, flooding is mainly confined to the topographic trench that is the river channel. The flooded area for the Standard Project Flood extends out of the channel area in some places, particularly in the 100-F Area. All of the output from the simulations have been archived and are available for future investigations in the Hanford Reach.

Suggested citation for this report is as follows:

Waichler SR, JA Serkowski, WA Perkins, and MC Richmond. 2017. Simulation of Columbia River Floods in the Hanford Reach. PNNL-26204, Pacific Northwest National Laboratory, Richland, Washington 


\section{Acknowledgments}

The authors thank PNNL staff Cindy Rakowski and Susan Ennor for their assistance with completing the project and report. We also thank Frank Hamada (Mission Support Alliance) and Diori Kreske (US Department of Energy) for their contributions to the project. 


\section{Acronyms and Abbreviations}

$\begin{array}{ll}\text { cfs } & \text { cubic feet per second } \\ \mathrm{cm} & \text { centimeter(s) } \\ \text { DOE } & \text { U.S. Department of Energy } \\ \text { FFRMS } & \text { Federal Flood Risk Management Standard } \\ \text { HRFCPPA } & \text { Hanford Reach Fall Chinook Protection Program Agreement } \\ \text { kcfs } & \text { thousand cubic feet per second } \\ \text { km } & \text { kilometer(s) } \\ \text { m } & \text { meter(s) } \\ \text { MAE } & \text { mean absolute error } \\ \text { MASS1 } & \text { Modular Aquatic Simulation System in 1 Dimension } \\ \text { mi } & \text { mile(s) } \\ \text { min } & \text { minute(s) } \\ \text { mm } & \text { millimeter(s) } \\ \text { NAVD88 } & \text { North American Vertical Datum of 1988 } \\ \text { NGVD29 } & \text { National Geodetic Vertical Datum of 1929 } \\ \text { NRG } & \text { North River Gage } \\ \text { PMF } & \text { Probable Maximum Flood } \\ \text { PRD } & \text { Priest Rapids Dam } \\ \text { RM } & \text { river mile(s) } \\ \text { SPF } & \text { Standard Project Flood } \\ \text { USACE } & \text { U.S. Army Corps of Engineers } \\ \text { USGS } & \text { U.S. Geological Survey }\end{array}$




\section{Contents}

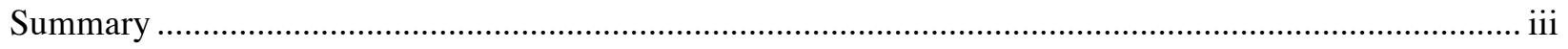

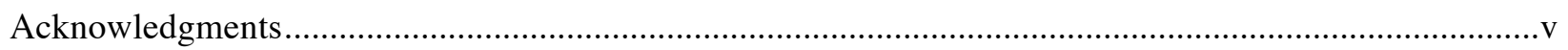

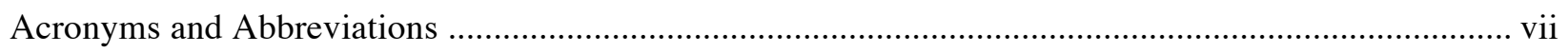

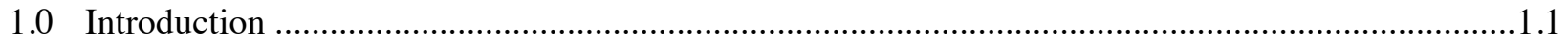

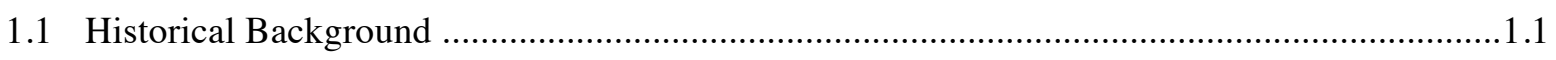

1.2 Federal Requirements for Flood Hazard Analysis ...........................................................

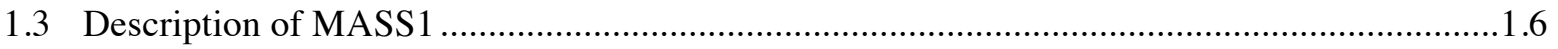

1.4 Previous Applications of MASS1 in the Hanford Reach ...................................................... 1.6

1.5 Report Contents and Organization ................................................................................. 1.7

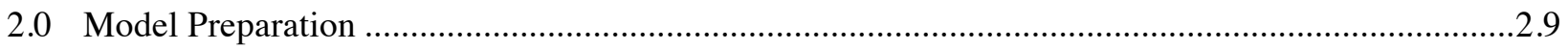

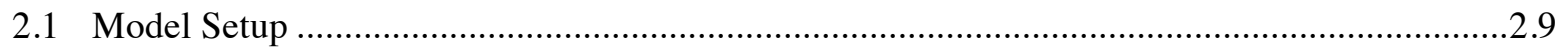

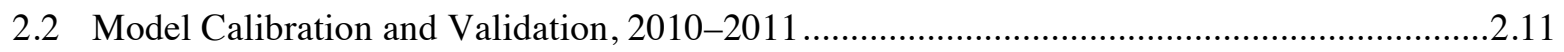

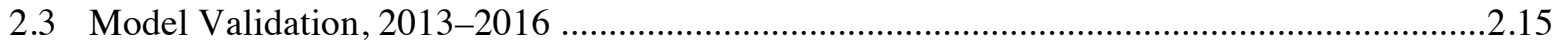

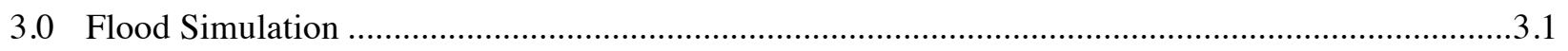

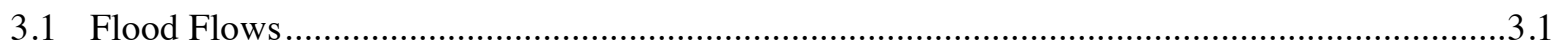

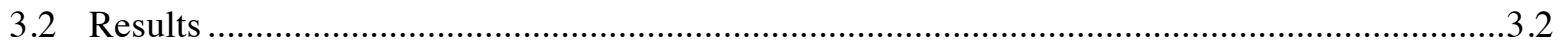

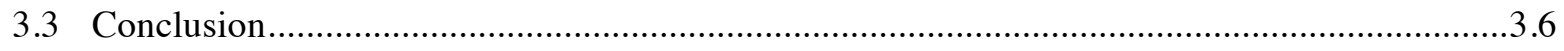

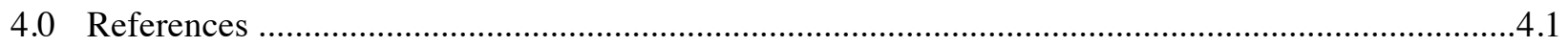

Appendix A - Estimated Peak Flow Rates for the Columbia River Near the Hanford Reach ..................A.1

Appendix B - Goodness-of-Fit Statistics Used in Calibration and Validation ........................................1 


\section{Figures}

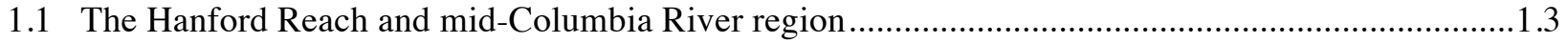

1.2 Mean daily Columbia River flow at Priest Rapids Dam, 1917-2004 ............................................ 1.4

1.3 Annual Columbia River runoff volume below Priest Rapids Dam, 1917-2013 .............................. 1.5

2.1 MASS1 topology for the mid-Columbia. Segment 1 includes the Hanford Reach,

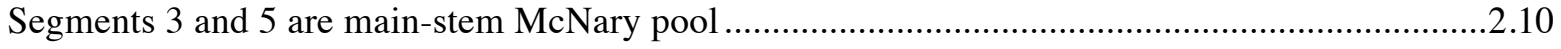

2.2 MASS1 cross sections in the Hanford Reach...........................................................................

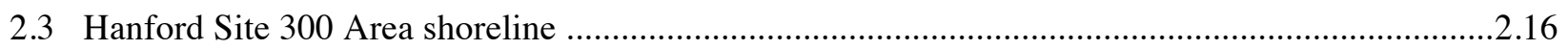

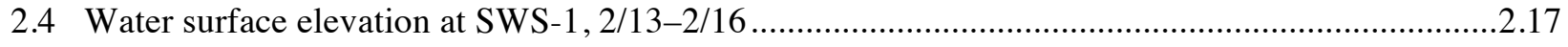

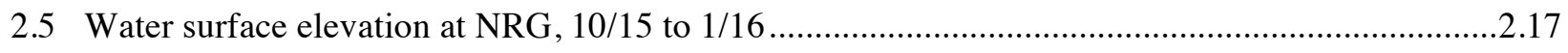

3.1 Hanford Reach water elevation profiles for three flood flows .......................................................3.3

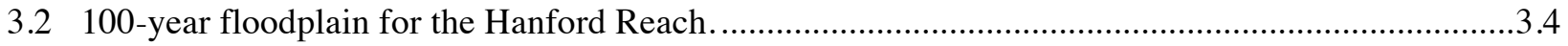

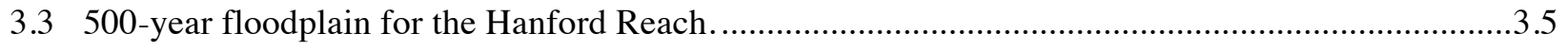

3.4 Standard Project Flood floodplain for the Hanford Reach ............................................................

\section{Tables}

1.1 Dam projects in the Middle and Upper Columbia River Basin

2.1 Model fit statistics and calibrated Manning's n values for MASS1 model in the Hanford Reach 2.13

3.1 Flood flow (discharge) rates for the mid-Columbia Basin 


\subsection{Introduction}

Columbia River elevations and flows in the Hanford Reach affect the environment and facilities along the shoreline, including movement of contaminants in groundwater, fish habitat, and infrastructure subject to flooding. This report describes the simulation of hypothetical flood flows using the best available topographic and bathymetric data for the Hanford Reach and the Modular Aquatic Simulation System in 1 Dimension (MASS1) hydrodynamic model. The MASS1 model of the Hanford Reach was previously calibrated to historical conditions and the current model setup can be used for other studies of flow, water levels, and temperature in the Reach.

Brief reviews of 1) historical Columbia River flow data at the site of Priest Rapids Dam and changes caused by the development of the hydropower projects; 2) federal requirements for flood hazard analysis; 3) MASS1 model characteristics; and 4) previous MASS1 applications to the Hanford Reach are provided below.

\subsection{Historical Background}

The upper part of the Hanford Reach, located in south-central Washington State, is the only remaining unimpounded reach of the Columbia River in the United States upstream of Bonneville Dam (Figure 1.1). The Columbia River upstream of the Reach is heavily regulated by upstream storage reservoirs (e.g., Grand Coulee Dam) and several run-of-river dams in the United States (Table 1.1). Priest Rapids Dam (PRD) at river mile 397.1 directly regulates flow into the Hanford Reach. Water levels in the lower end of the Reach near Richland, Washington, are also influenced by the pool levels at McNary Dam and tributary flows from the Snake River and Yakima River, all located downstream from the Reach.

The first dam constructed on the Columbia River upstream of the Hanford Site was Rock Island, a run-ofriver project with little storage that began operation in 1933 (Table 1.1). The first large storage project was Grand Coulee; its operation increased fluctuations in the daily hydrograph during the fall and early winter baseflow period after its start in 1942 (Figure 1.2). More changes are visible in the hydrograph after the large flood of 1948, and there were larger and more frequent fluctuations in the baseflow period of summer and fall after PRD came online in 1961.

In addition to changes in storage throughout the basin, operational and environmental policy affecting river flows has been implemented over the past 100 years. The Vernita Bar Agreement of 1988, for which flow changes began during 1984, and the Hanford Reach Fall Chinook Protection Plan Agreement (HRFCPPA) of 2004 dictated two major changes to operations at PRD. Changes in annual runoff volume at PRD are shown in Figure 1.3. Relatively large daily fluctuations in discharge at PRD are required during some seasons to meet electricity demand and flood-control objectives. This change in flow regime has a large impact on the water levels, temperature, and stream habitat within the Hanford Reach.

Prior to dam construction, annual Columbia River discharge peaks could exceed $600 \mathrm{kcfs}$ through the Hanford Reach, and the flood of record was $742 \mathrm{kcfs}$, which occurred in 1894 . As the number of upstream dams increased, flow peaks decreased and base flows increased; current annual peaks through the Hanford Reach are a little over 300 kcfs. Since 1974 only one year, 1997, had a relatively high annual maximum $-455 \mathrm{kcfs}$. 
Table 1.1. Dam projects in the Middle and Upper Columbia River Basin (from Niehus et al. 2014).

\begin{tabular}{|c|c|c|c|c|c|}
\hline Dam Name & Location & Owned by & Date Completed & $\begin{array}{c}\text { Storage Volume } \\
\text { ( M Arce-ft) }\end{array}$ & $\begin{array}{l}\text { Cumulative } \\
\text { Storage Volume }\end{array}$ \\
\hline Thompson Falls & Clark Fork River, ID & PPL Montana & 1917 & 0.4 & 0.40 \\
\hline Corra Linn & Kootenay River, BC & W. Kootenay & 1932 & 7.10 & 7.50 \\
\hline Rock Island & Columbia River, WA & Chelan Co. PUD & 1933 & 0.13 & 7.63 \\
\hline Kerr & Flat River, MT & Montana Power Comission & 1938 & 1.22 & 8.85 \\
\hline Grand Coulee & Columbia River, WA & Bureau of Reclimation & 1942 & 5.19 & 14.04 \\
\hline Duncan & Duncan River, BC & BC Hydro & 1948 & 1.40 & 15.44 \\
\hline Hungry Horse & South Fork of Flat River, MT & Bureau of Reclimation & 1953 & 3.16 & 18.60 \\
\hline Cabinet Gorge & Clark Fork River, ID & Avista & 1953 & 0.04 & 18.64 \\
\hline Waneta Dam & Pend Oreille River, BC & Teck Cominco & 1954 & 0.004 & 18.65 \\
\hline Albeni Falls & Pend Oreille River, ID & Corps of Engineers & 1955 & 1.16 & 19.81 \\
\hline Chief Joseph & Columbia River, WA & Corps of Engineers & 1955 & 0.52 & 20.32 \\
\hline Box Canyon & Pend Oreille River, WA & Pend Oreille County PUD & 1956 & 0.06 & 20.38 \\
\hline Noxon Rapids & Clark Fork River, ID & Avista & 1960 & 0.23 & 20.61 \\
\hline Rocky Reach & Columbia River, WA & Chelan Co. PUD & 1961 & 0.38 & 20.99 \\
\hline Priest Rapids & Columbia River, WA & Grant Co. PUD & 1961 & 0.28 & 21.27 \\
\hline Wanapum & Columbia River, WA & Grant Co. PUD & 1964 & 0.80 & 22.07 \\
\hline Boundary & Pend Oreille River, WA & Seattle City Light & 1967 & 0.10 & 22.17 \\
\hline Wells & Columbia River, WA & Douglas Co. PUD & 1967 & 0.33 & 22.50 \\
\hline Keenleyside & Columbia River, BC & BC Hydro & 1968 & 7.10 & 29.60 \\
\hline Mica & Columbia River, BC & BC Hydro & 1973 & 20.10 & 49.70 \\
\hline Libby & Kootenay River, MT & Corps of Engineers & 1975 & 4.98 & 54.68 \\
\hline Seven Mile & Pend Oreille River, BC & BC Hydro & 1981 & 0.02 & 54.70 \\
\hline Revelstoke & Columbia River, BC & BC Hydro & 1984 & 1.23 & 55.93 \\
\hline
\end{tabular}




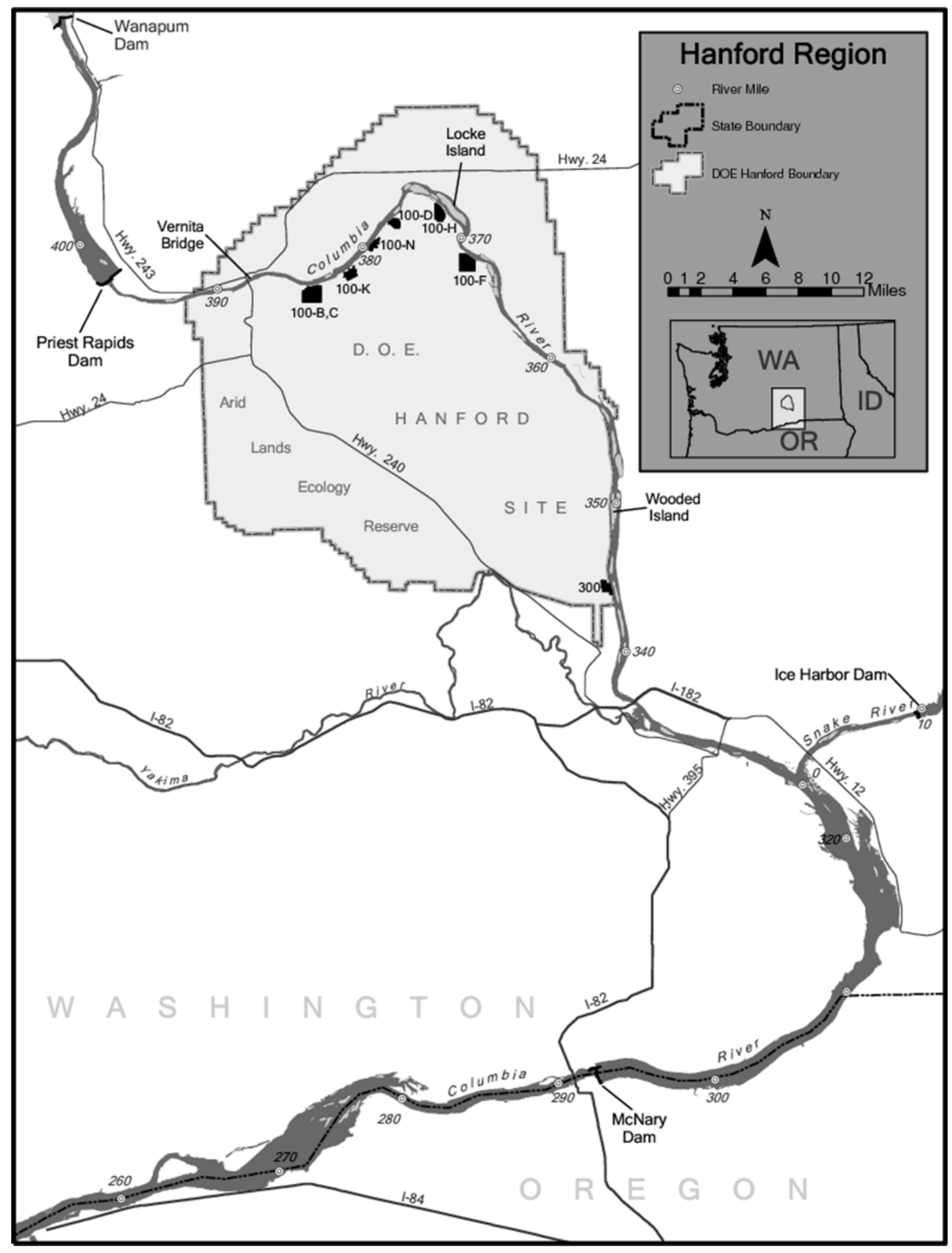

Figure 1.1. The Hanford Reach and mid-Columbia River region. 

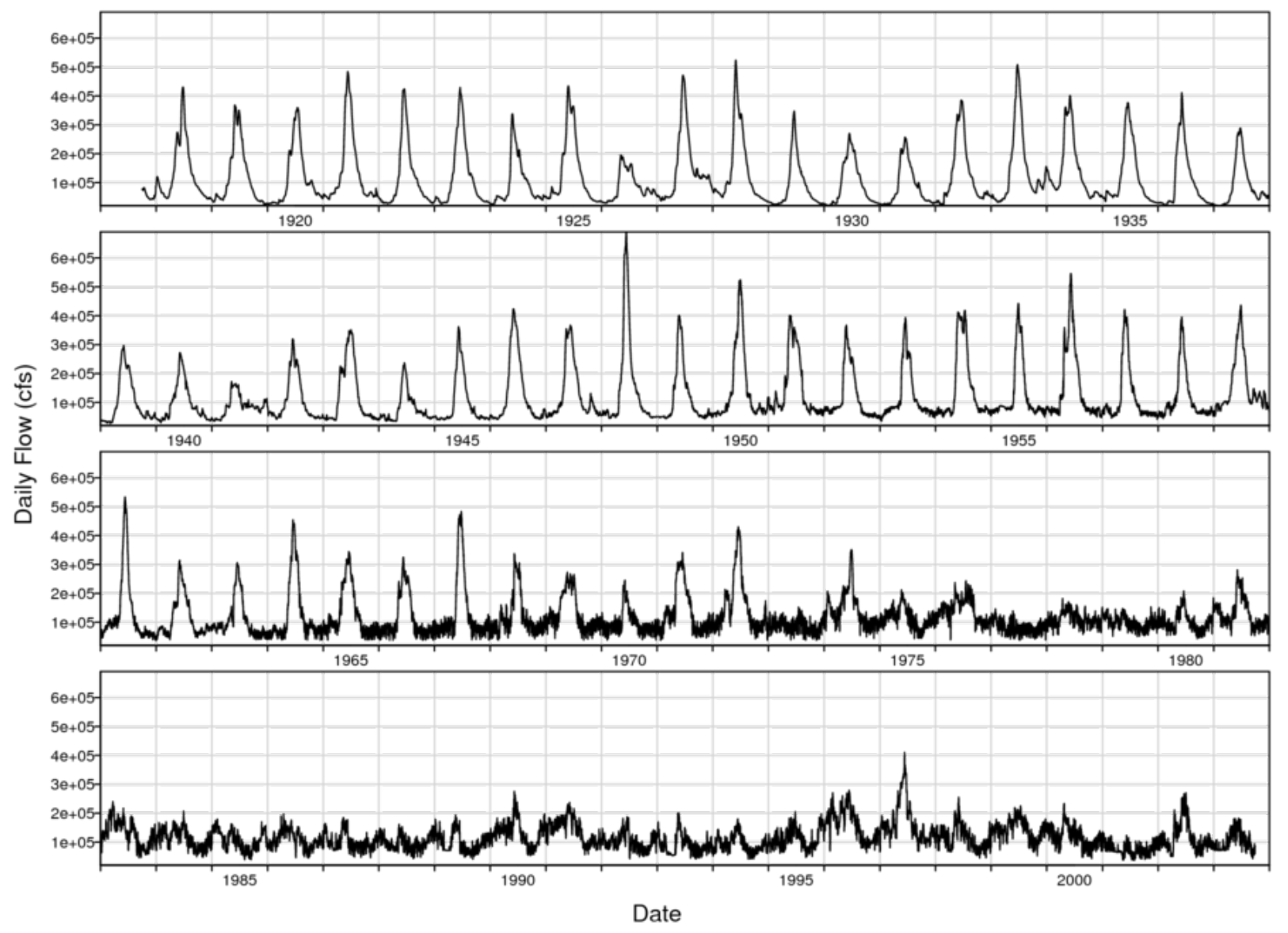

Figure 1.2. Mean daily Columbia River flow at Priest Rapids Dam, 1917-2004 (from Waichler et al. 2005). 


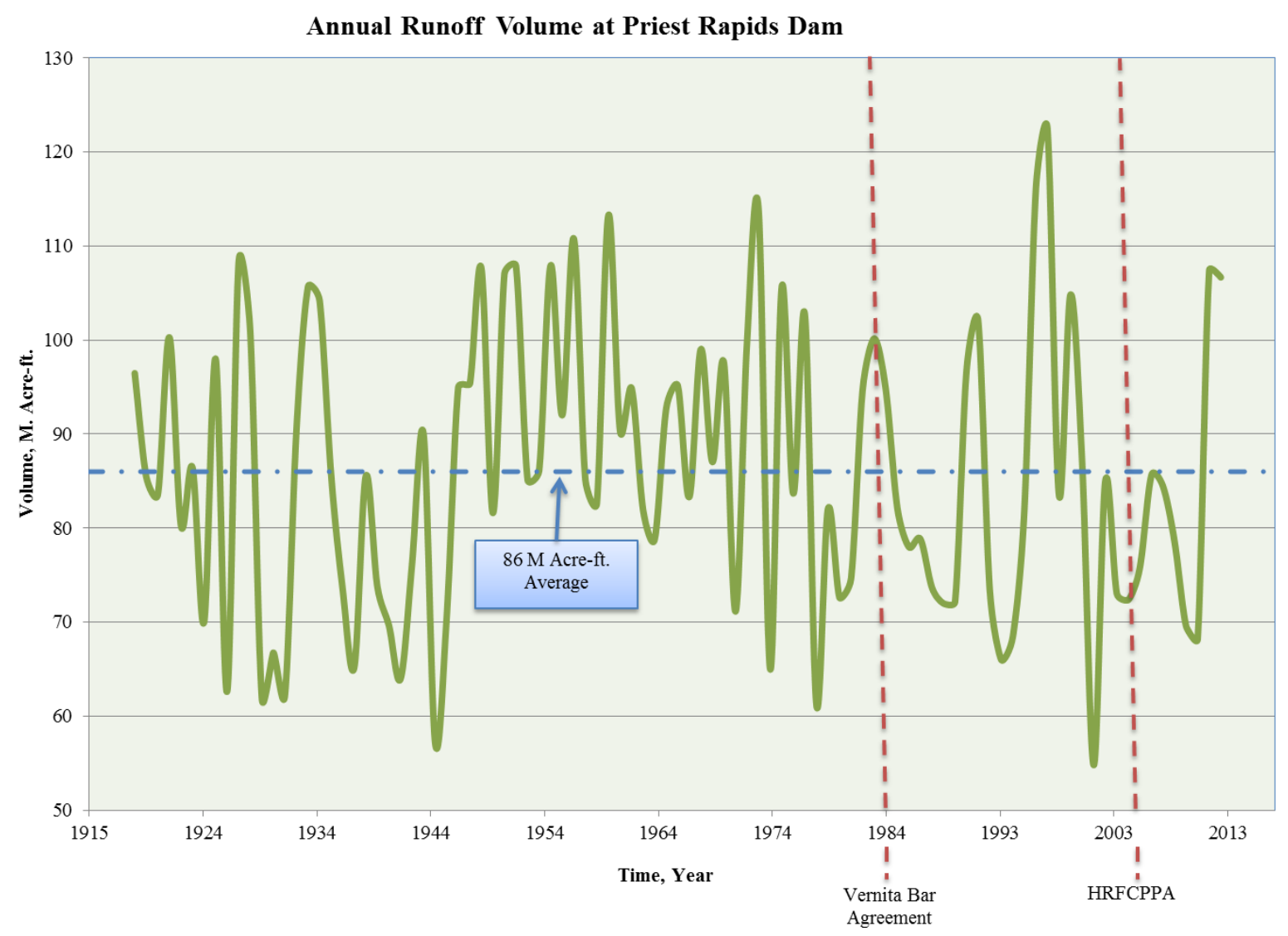

Figure 1.3. Annual Columbia River runoff volume below Priest Rapids Dam (USGS gage 12472800), 1917-2013 (from Niehus et al. 2014).

\subsection{Federal Requirements for Flood Hazard Analysis}

Federal agencies are required to manage floodplains in accordance with "Guidelines for Implementing Executive Order 11988 . . . and Executive Order 13690" (FEMA 2015, hereafter "Guidelines"). Federal agencies are required to evaluate potential impacts from flood hazards on any proposed actions in a qualifying floodplain (10 CFR Part 1022). The Guidelines incorporate the Federal Flood Risk Management Standard (FFRMS) and amendments found in Executive Order 13690 and describe various approaches for determining the vertical flood elevation and corresponding horizontal floodplain for federally funded projects. The FFRMS it is not meant to be an "elevation" standard but rather a resilience standard. The vertical flood elevation and corresponding horizontal floodplain determined using the approaches in the FFRMS establish the area in which a structure or facility must be resilient. This may include using structural or nonstructural methods to reduce or prevent damage; elevating a structure; or, where appropriate, designing it to adapt to, withstand and rapidly recover from a flood event.

\section{The Guidelines state}

"For federally funded projects, agencies must, at a minimum, use one of the following approaches to determine the vertical flood elevation and corresponding horizontal floodplain for a given action: 
1. Climate-informed Science Approach (CISA) - use the best available, actionable hydrologic and hydraulic data and methods that integrate current and future changes in flooding based on climate science.

2. Freeboard Value Approach (FVA) -use the Base Flood Elevation (or 1-percentannual-chance flood determined using best available data; also known as the 100year flood) and an additional height to calculate the freeboard value. The additional height is 2 feet for noncritical actions and 3 feet in elevation for critical actions. A critical action is one for which even a slight chance of flooding would be too great. Such actions may include, but are not limited to, the storage of highly volatile, toxic, or water reactive materials.

3. The 0.2-percent-annual-chance Flood Approach (0.2PFA) - use the 0.2-percentannual-chance flood elevation (also known as the 500-year flood elevation)."

This background of requirements guided the choice of using 100-year and 500-year floods in the analysis.

\subsection{Description of MASS1}

The MASS1 numerical hydraulic model calculates cross-section-averaged hydraulic and, optionally, water temperature conditions in open channel systems, including rivers, reservoirs, and estuaries. Primary data requirements include bathymetry (river bottom elevation) as a series of cross sections, river inflow data applied at the upstream end of the main stem, any additional lateral inflows downstream, and a downstream water surface elevation at the end of the network. Simulation of water temperature also requires upstream inflow temperature and meteorological data to calculate heat exchange across the airwater interface. Because MASS1 uses cross-section averaging, only single values of water surface elevation, velocity, discharge, and temperature are produced at each cross-section location along the river course. Lateral (i.e., across the river channel) and vertical variations of these quantities are not simulated. Each bathymetric cross section is a series of elevations along a line (not necessarily straight) extending laterally across the river. Cross sections for natural waterways such as rivers are defined from topographic or bathymetric surveys.

\subsection{Previous Applications of MASS1 in the Hanford Reach}

MASS 1 is a one-dimensional unsteady hydrodynamic and water quality model capable of simulating open channel flows, water surface elevations, and water temperature. MASS1 is applicable to any branched channel system and has been successfully applied by the Pacific Northwest National Laboratory (PNNL) for over 20 years to simulate the Columbia River from the Canadian border to McNary Dam to address a variety of demands for river information. MASS1 output is well suited to reconstructing historical or building future scenarios of river elevations and water temperatures to investigate environmental problems such as groundwater-river interaction or fish habitat changes. Because flow, elevation, and temperature data are very expensive to collect in the field, a physics-based numerical model such as MASS1 is the only practical way to characterize river conditions at sufficient spatial and temporal densities for most purposes, both in the past and in possible future scenarios.

MASS1 has been used to simulate water temperature and total dissolved gas (Richmond et al. 2000), and to compare water quality under impounded and unimpounded conditions (Perkins and Richmond 2001; Perkins et al. 2002). The phenomenon of dewatering and stranding of fish in isolated pools was studied by Perkins et al. (2002), McMichael et al. (2006), and Richmond and Perkins (2009). A decades-long period 
of flows and water levels was evaluated by Waichler et al. (2005). Improvements in the resolution of bathymetric data (Coleman et al. 2010) made it desirable to reconfigure, recalibrate, and revalidate the MASS1 model for the Hanford Reach. Niehus et al. (2014) did this and simulated another long time period, with the addition of temperature. Additional validation using stage and temperature data from 2013-2016 in the 300 Area was subsequently done. The goodness of fit between observed and simulated water levels and temperature for the current model configuration are described in Section 2.0.

\subsection{Report Contents and Organization}

Section 2 that follows describes the current MASS1 model setup for the Hanford Reach, including previous model calibration and validation using 2010-2011 and 2013-2016 data. Section 3 reviews 100year and more severe flood flow rates from the literature, and gives the results of simulating those flows in steady state and mapping the inundated areas in the Hanford Reach. Appendix A contains the Columbia River discharge vs. flood probability $\operatorname{plot}^{1}$ that was used to assign the flood flow rates to be simulated. Appendix B defines the goodness-of-fit statistics used in reporting calibration and validation results.

\footnotetext{
${ }^{1}$ Provided by the U.S. Army Corps of Engineers (USACE)
} 


\subsection{Model Preparation}

Preparation of the numerical model involved setup, calibration, and validation which are described in this section. Note that reference is made to several Hanford Site operating Areas (100-B, 100-F, 300 Area, etc) that were originally designated during the period when the Site was actively operating reactors and associated processing facilties.

\subsection{Model Setup}

The MASS1 topology used in this work was unchanged from previous Hanford Reach applications (Niehus et al. 2014). The river network is divided into a series of links along which computational points are located (Figure 2.1). The representation is a branched system comprising nodes where volumetric flow rate or water surface elevation are specified and channel segments join the nodes. The simulated domain includes the Columbia River from PRD to McNary Dam and the Snake River from Ice Harbor Dam to its mouth. Links are used to represent the Columbia and Snake Rivers. Yakima River discharge is included as a tributary inflow.

MASS1 simulations of water flow and elevation (stage) in the Hanford Reach require the following boundary conditions: 1) Columbia River flow from PRD, 2) Snake River flow from Ice Harbor Dam, 3) Yakima River flow at Kiona, and 4) Columbia River pool elevation at McNary Dam. In most studies of the Hanford Reach, the boundary conditions have been historic and time-varying conditions, typically hourly or daily. For this study, all of the above boundary conditions were set to constants and the simulations were run to steady state. In an actual flood, the time-variant water levels may be important for some purposes, but they were not considered in this study.

The current bathymetric data set was developed for the entire Hanford Reach from PRD to the mouth of the Yakima River by Coleman et al. (2010). Elevations beyond the wetted channel were extended with a $10 \mathrm{~m}$ U.S. Geological Survey (USGS) digital elevation model, so that cross sections could extend into areas that would be inundated at higher discharges. Cross-section data were then generated from the bathymetry/topography surface as described in the methods of Richmond et al. (2000). Cross sections were placed every $0.24 \mathrm{~km}$ apart and extended approximately $610 \mathrm{~m}$ laterally (Figure 2.2). The MASS1 model contains 395 cross sections on the Columbia River through the Hanford Reach. 


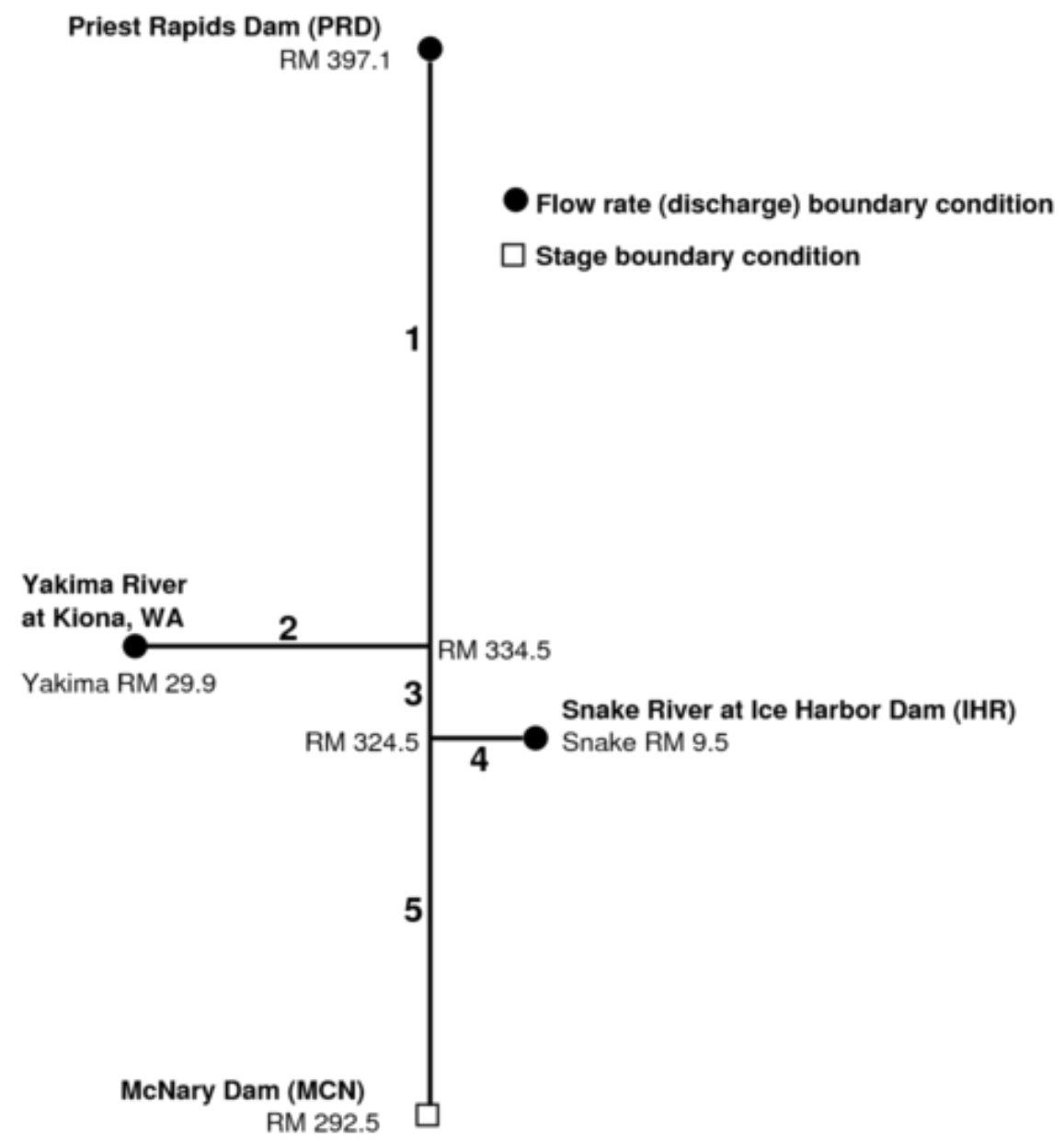

Figure 2.1. MASS1 topology for the mid-Columbia. Segment 1 includes the Hanford Reach, Segments 3 and 5 are main-stem McNary pool. River miles (RM) are Columbia River unless otherwise noted. 


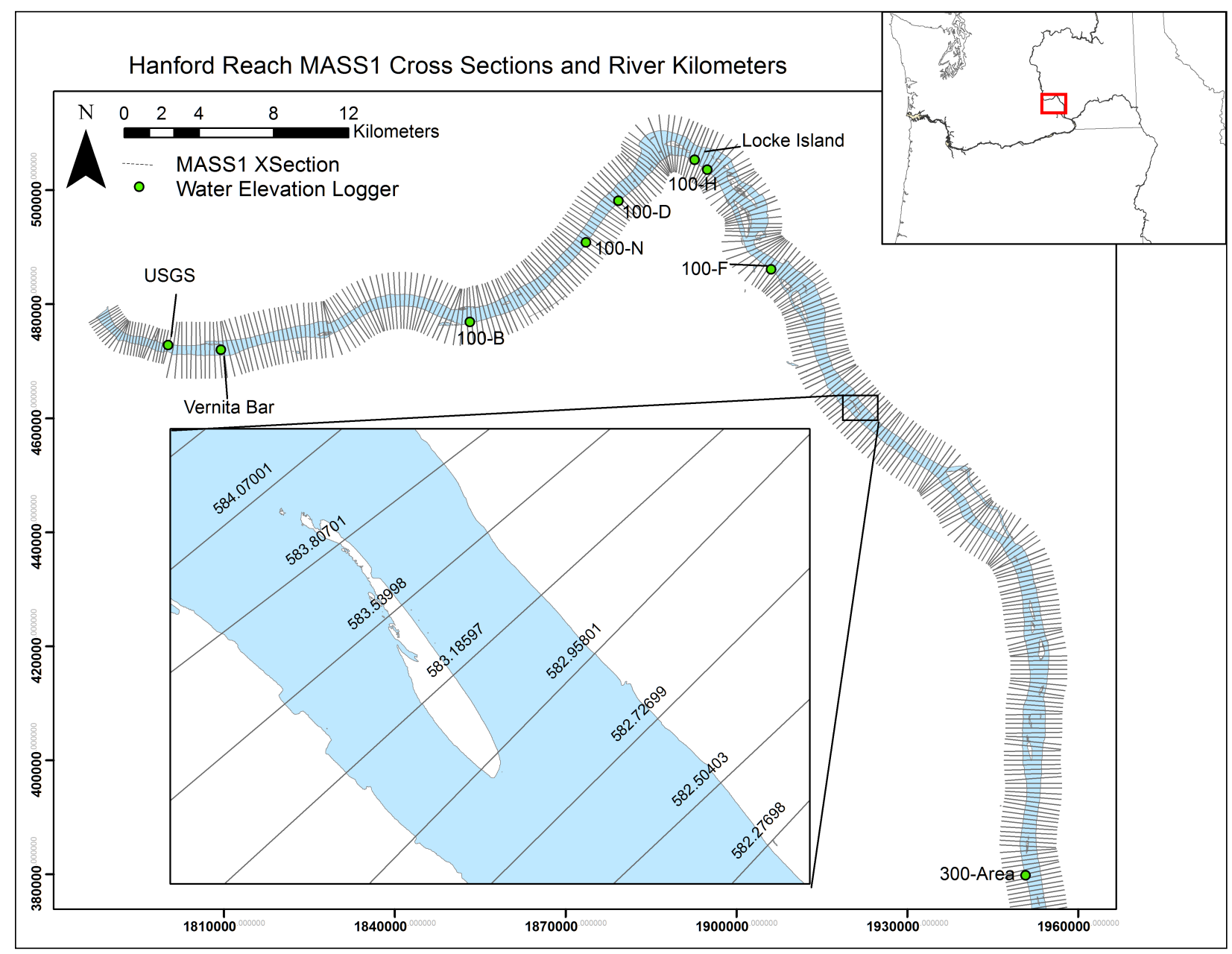

Figure 2.2. MASS1 cross sections in the Hanford Reach.

Although MASS1 is configured to simulate the Columbia River from PRD to McNary Dam, the current configuration was calibrated and validated using observations from only the Hanford Reach.

\subsection{Model Calibration and Validation, 2010-2011}

The current configuration of MASS1 was calibrated and checked using historic data from 2010-2011 (Niehus et al. 2014). Calibration consisted of subdividing the Reach into nine segments based on datalogger locations (Table 2.1, Figure 2.3), and adjusting the roughness coefficient (Manning's n) for each segment, starting at the most downstream segment until the mean simulated stage matched those recorded by the datalogger within a $2 \mathrm{~mm}$ tolerance (bias statistic, Appendix B). Calibration continued upstream until the bias at all dataloggers was within the tolerance. The period for flow calibration was $10 / 3 / 2010-3 / 7 / 2011$. The model was run with a 6 min time step and outputs were saved at hourly intervals. The roughness coefficients (Manning's n) for MASS1 ranged from 0.0254 to 0.0340, which are reasonable values for the Columbia River. Simulated stage at the nine datalogger locations during the calibration period had a mean absolute error (MAE, Appendix B) ranging from 3.7 to $17.6 \mathrm{~cm}$ (Table 2.1).

The period for validation was from 7/1/2011-9/1/2011. Columbia River flows in the first half of summer, May through July, are typically the largest but tend to level off through July and decrease through to the 
fall. The discharge in late summer 2011 was fairly high ( $>300 \mathrm{kcfs}$ ) and gradually dropped to a range of $100 \mathrm{kcfs}$ to $50 \mathrm{kcfs}$. Fall discharges were varied and generally lower. The chosen validation period ensured that the MASS1 model would be exercised at both high and low Hanford Reach discharges. Dataloggers at Vernita Bar and Locke Island were removed in late February, so statistics were not available for those locations. As typically happens, the goodness of fit of the simulation to the measured values was lower in the validation period than in the calibration period. The MAE for the validation ranged from 4.0 to $49.0 \mathrm{~cm}$ (Table 2.1). This overprediction was expected, because that the model was calibrated at lower flows.

Taken as a whole, these goodness-of-fit statistics for stage indicate that the current MASS1 configuration does a good job of simulating water surface elevations in the Hanford Reach. 
Table 2.1. Model fit statistics and calibrated Manning's n values for MASS1 model in the Hanford Reach (Niehus et al. 2014).

\begin{tabular}{|c|c|c|c|c|c|c|c|c|c|c|c|c|c|}
\hline \multirow[t]{2}{*}{$\begin{array}{l}\text { Datalogger } \\
\text { Location }\end{array}$} & \multicolumn{2}{|c|}{ River Segment (mi) } & \multirow[t]{2}{*}{$\begin{array}{c}\text { Manning's } \\
\mathrm{n}\end{array}$} & \multicolumn{2}{|c|}{$\begin{array}{c}\text { Calibration, Stage } \\
10 / 3 / 2010- \\
3 / 7 / 2011 \\
\end{array}$} & \multicolumn{2}{|c|}{$\begin{array}{l}\text { Validation, } \\
\text { Stage } \\
7 / 1 / 2011- \\
9 / 1 / 2011 \\
\end{array}$} & \multicolumn{2}{|c|}{$\begin{array}{c}\text { Validation, Stage } \\
2 / 6 / 2013- \\
1 / 28 / 2016 \\
\end{array}$} & \multicolumn{2}{|c|}{$\begin{array}{c}\text { Validation, } \\
\text { Temperature } \\
\text { 10/3/2010- } \\
12 / 12 / 2010 \\
\end{array}$} & \multicolumn{2}{|c|}{$\begin{array}{c}\text { Validation, } \\
\text { Temperature } \\
\text { 2/6/2013-1/28/2016 }\end{array}$} \\
\hline & Start & Stop & & $\begin{array}{l}\text { Bias } \\
(\mathrm{cm})\end{array}$ & $\begin{array}{l}\text { MAE } \\
(\mathrm{cm})\end{array}$ & $\begin{array}{l}\text { Bias } \\
(\mathrm{cm})\end{array}$ & $\begin{array}{l}\text { MAE } \\
(\mathrm{cm})\end{array}$ & $\begin{array}{l}\text { Bias } \\
(\mathrm{cm})\end{array}$ & $\begin{array}{l}\text { MAE } \\
(\mathrm{cm})\end{array}$ & $\begin{array}{l}\text { Bias } \\
(\mathrm{C}) \\
\end{array}$ & $\begin{array}{l}\text { MAE } \\
(\mathrm{C})\end{array}$ & $\begin{array}{c}\text { Bias } \\
(\mathrm{C})\end{array}$ & $\begin{array}{c}\text { MAE } \\
(\mathrm{C}) \\
\end{array}$ \\
\hline USGS & 394.55 & 392.72 & 0.0321 & 0.00 & 5.8 & 12.0 & 49.0 & & & 0.15 & 0.45 & & \\
\hline Vernita Bar & 392.72 & 384.08 & 0.0298 & 0.20 & 12.2 & NA & NA & & & 0.70 & 1.11 & & \\
\hline $100-B$ & 384.08 & 379.41 & 0.0330 & -0.20 & 17.6 & 24.0 & 26.0 & & & -0.20 & 0.45 & & \\
\hline $100-\mathrm{N}$ & 379.41 & 377.53 & 0.0313 & 0.00 & 15.6 & 27.0 & 30.0 & & & 0.00 & 0.43 & & \\
\hline $100-\mathrm{D}$ & 377.53 & 373.71 & 0.0340 & 0.20 & 16.1 & 19.0 & 22.0 & & & 0.20 & 0.32 & & \\
\hline Locke Is. & 373.71 & 373.03 & 0.0346 & 0.10 & 4.8 & NA & NA & & & 0.10 & 0.21 & & \\
\hline $100-\mathrm{H}$ & 373.03 & 368.71 & 0.0265 & 0.20 & 6.4 & -1.0 & 4.9 & & & 0.20 & 0.26 & & \\
\hline $100-\mathrm{F}$ & 368.71 & 356.59 & 0.0296 & 0.20 & 7.9 & 19.0 & 22.0 & & & 0.20 & 0.25 & & \\
\hline 300 Area & 356.59 & 334.48 & 0.0254 & -0.10 & 3.7 & 1.0 & 4.0 & -0.4 & 5.01 & -0.10 & 0.20 & -0.04 & 0.39 \\
\hline NRG & & & & & & & & 3.9 & 6.94 & & & -0.86 & 0.86 \\
\hline
\end{tabular}




\subsection{Model Validation, 2013-2016}

Subsequent to the efforts by Niehus et al. (2014), the Hanford Reach model was rerun to simulate the historic period from December 2009 to January 2016. Simulated water surface (SWS) elevation was compared to measured values at two locations in the 300 Area, SWS-1 (same as "300 Area" location in Section 2.2) and NRG ("North River Gage"), located upstream from SWS-1 at RM 344.793 (Figure 2.3).

The history match for the 2013-2016 period is good, especially considering that the current calibration 1) was done with 2010-2011 data, and 2) gave equal weight to many stations in the entire Hanford Reach. The MAEs for stage were 5.01 and $6.94 \mathrm{~cm}$ for SWS-1 and NRG, respectively (Table 2.1). Plots of simulated and observed stages are given in Figure 2.4 and Figure 2.5. The model skill of MASS1 for this time period and these locations further demonstrates the suitability of the current model configuration for simulating conditions in the Hanford Reach. 


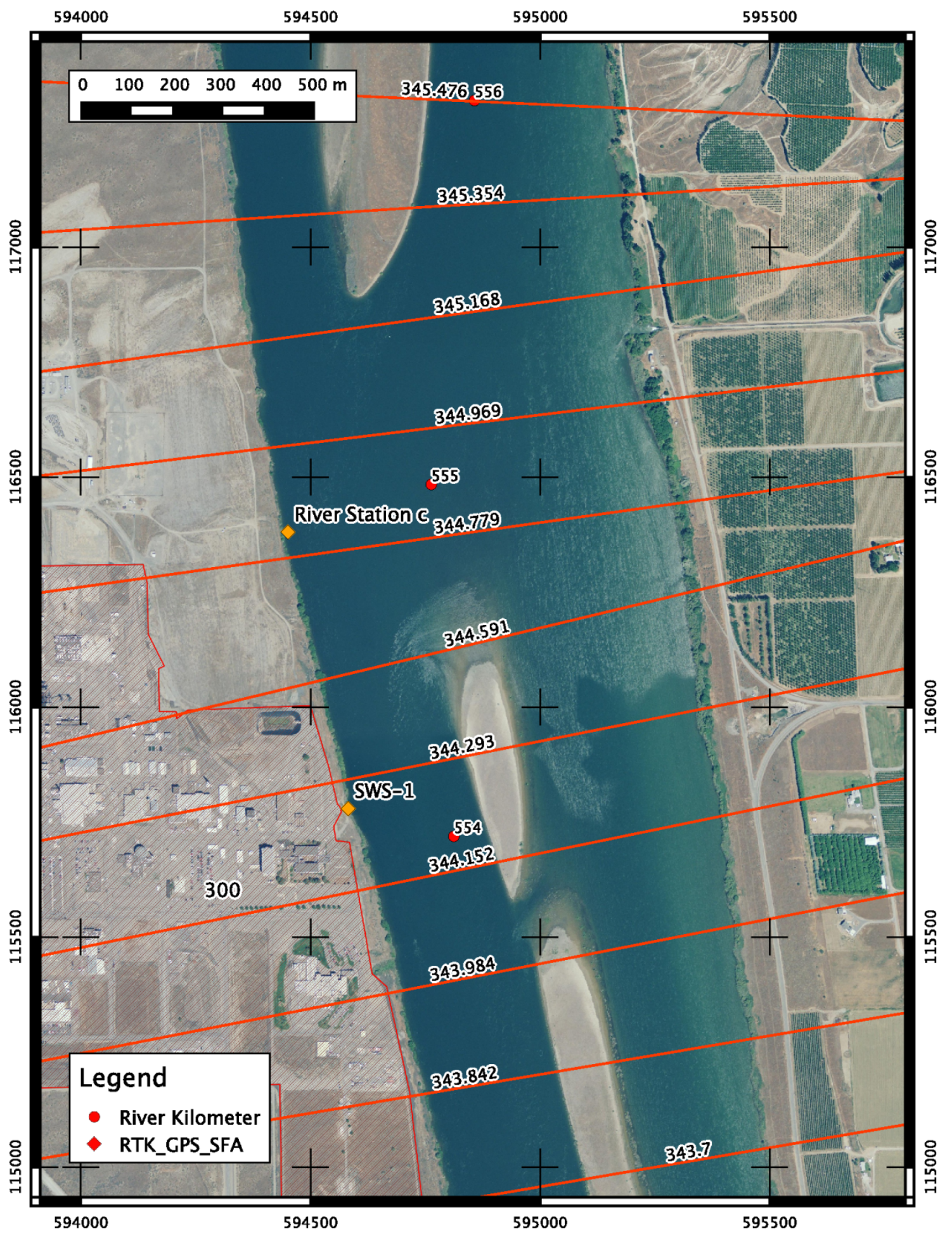

Figure 2.3. Hanford Site 300 Area shoreline. Red lines across river are MASS1 cross sections, which are labeled with Columbia River miles. River Station c $=$ North River Gage (NRG). SWS-1 is the primary water gage in the 300 Area. 


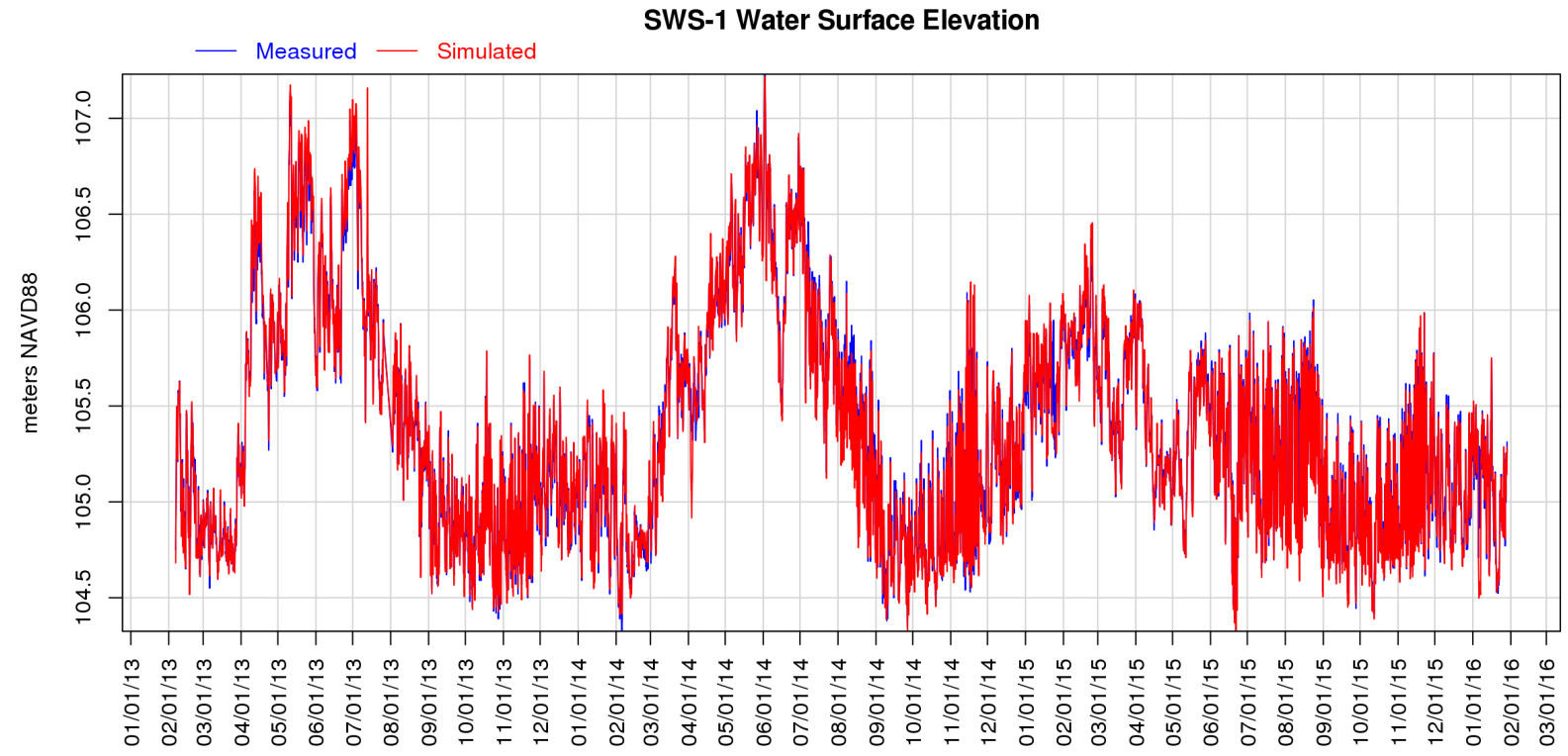

Figure 2.4. Water surface elevation at SWS-1, 2/13-2/16.

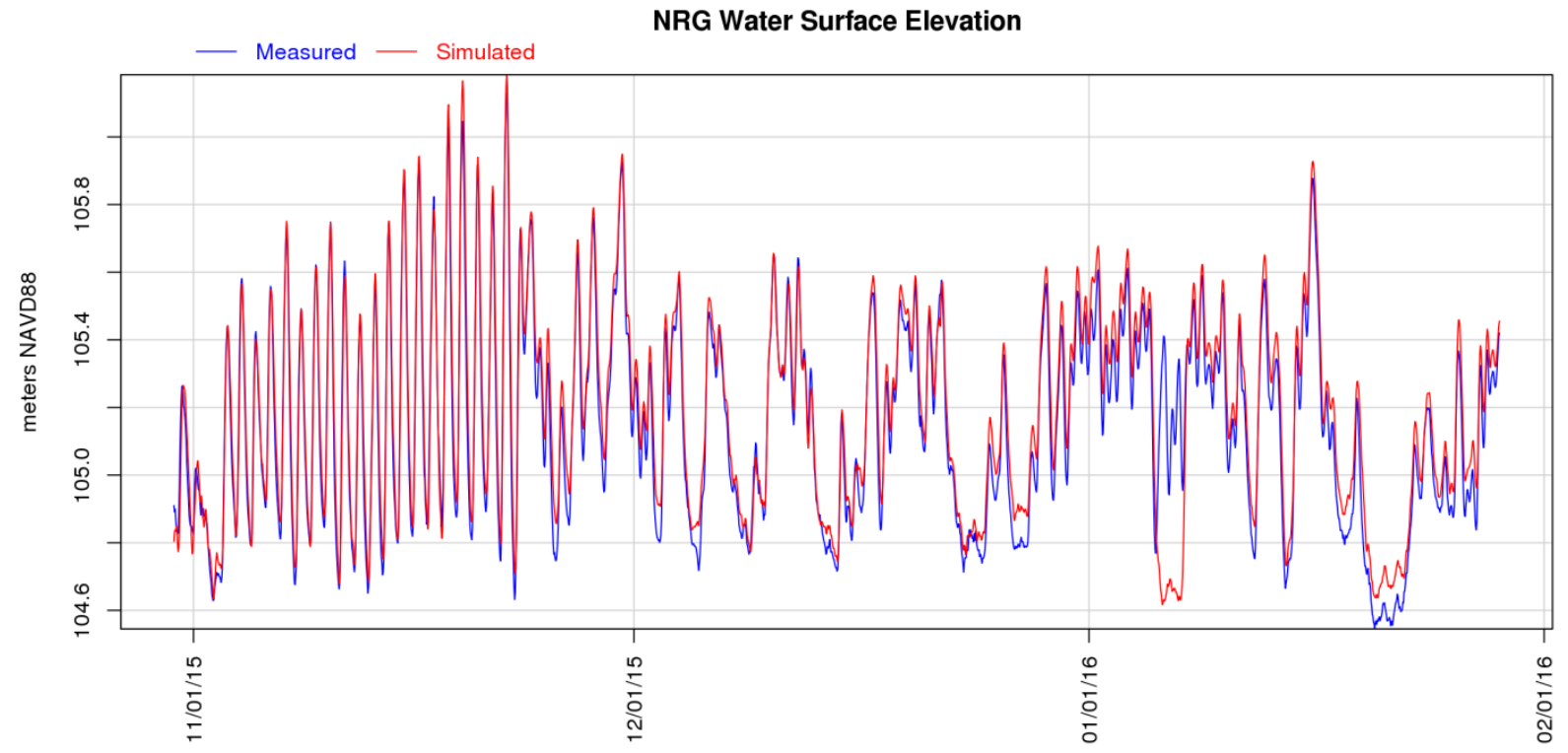

Figure 2.5. Water surface elevation at NRG, 10/15 to $1 / 16$. 


\subsection{Flood Simulation}

\subsection{Flood Flows}

Previous reports containing measured and estimated flood flow rates for the mid-Columbia River were reviewed and the key results are summarized in Table 3.1. According to the FEMA 2015 Guidelines, we included the 100-year and 500-year floods. In both cases, regulated (i.e., with the current dam regime in place and functioning) flow rates were selected as being most realistic and representative of the potential hazard for the Hanford Site. We asked both the U.S. Army Corps of Engineers (USACE) and Grant County Public Utility District for the most current information regarding discharge estimates for floods in the Columbia, Yakima, and Snake Rivers (to simulate the Columbia River in the Hanford Reach, the Yakima and Snake River flows are also required as inputs to the hydrodynamic model). USACE responded with a line plot (USACE 2013) that contains discharge vs. probability for three flow levels: 1) Columbia River downstream of PRD, 2) Columbia + Yakima River, and 3) Columbia + Yakima + Snake River. These flood frequency curves were interpolated at the 100-year and 500-year flow levels for all three rivers (Table 3.1) for use in this modeling effort. The 100-year and 500-year Columbia River discharges below PRD are 445,000 and 520,000 cfs, respectively.

Several previous studies of flood risk at the Hanford Site were concerned with the possibility of a Probable Maximum Flood (PMF) from a natural hydrologic event, or flooding from failure of a major upstream storage dam such as Grand Coulee or Mica (e.g., Tallman 1996; McCann and Boissonnade 1988). A PMF is a flood that would result from the theoretically maximum possible runoff event in the Columbia Basin, which would be a combination of extreme rainfall and melting of a significant snowpack. Studies concerned with dam failure assumed that the cause would be an earthquake or a bomb. Much higher flow rates, in excess of 1 million cubic feet per second, are associated with a PMF or dam failure. However, these scenarios are considered extreme and not appropriate for most types of flooding evaluations. If a flood of this magnitude were to happen, the problems posed to the Pacific Northwest and the nation would be far greater than those inflicted on just the Hanford Site. Nevertheless, for additional illustration and to provide a severe upper bound for floodplain delineation, a third scenario involving much higher flows than even the 500-year flood was performed-the Unregulated Standard Project Flood used in the design and management of McNary Dam (Table 3.1). Columbia River flow for this scenario is 960,000 cfs.

No geometric or parameter changes were made to the current model configuration from Niehus et al. (2014) for this flood study. The only changes in the model input were the addition of the Columbia, Yakima, and Snake River flows. The constant flood flows along with the maximum normal operating level for the McNary Dam forebay (340 ft NGVD29 [National Geodetic Vertical Datum of 1929]) were used as the model boundary conditions, and the model was run in steady-state mode for the flood scenarios. 
Table 3.1. Flood flow (discharge) rates for the mid-Columbia Basin.

\begin{tabular}{|c|c|c|}
\hline Frequency or Rationale & Discharge (kcfs) & Reference \\
\hline \multicolumn{3}{|l|}{$\begin{array}{l}\text { Flood flow rates used in scenarios for this } \\
\text { report: }\end{array}$} \\
\hline 100 yr Columbia River below PRD, Regulated & 445 & USACE Walla Walla, Apr 2013 \\
\hline 100 yr Yakima River, Regulated & 35 & “ \\
\hline 100 yr Snake River, Regulated & 180 & “ \\
\hline 500 yr Columbia River below PRD, Regulated & 520 & “ \\
\hline 500 yr Yakima River, Regulated & 35 & “ \\
\hline 500 yr Snake River, Regulated & 215 & “ \\
\hline $\begin{array}{l}\text { Standard Project Flood, Columbia River below } \\
\text { PRD, Unregulated }\end{array}$ & 960 & USACE 1989 \\
\hline Standard Project Flood, Snake River, Unregulated & 575 & USACE 1989 \\
\hline $\begin{array}{l}\text { Standard Project Flood, Yakima River, } \\
\text { Unregulated }\end{array}$ & 70 & Estimated, see text \\
\hline \multicolumn{3}{|l|}{$\begin{array}{l}\text { Other Columbia River below PRD measured } \\
\text { and estimated flood discharges: }\end{array}$} \\
\hline $\begin{array}{l}\text { Standard Project Flood, Columbia River below } \\
\text { PRD, Regulated }\end{array}$ & 540 & USACE 1989 \\
\hline Standard Project Flood, Snake River, Regulated & 420 & USACE 1989 \\
\hline Flood of record, 6/7/1894 & 742 & Duncan 2007 \\
\hline $\begin{array}{l}2009 \text { Dams Sector Exercise for Tri-Cities levee } \\
\text { planning }\end{array}$ & 600 & Teasdale et al. 2009 \\
\hline 500 yr regulated & 540 & Tallman 1996 \\
\hline $\begin{array}{l}\text { Columbia River Treaty goals for flow at The } \\
\text { Dalles }\end{array}$ & 600,800 & USACE 2003 \\
\hline PMF, regulated & 1200 & McCann and Boissonnade 1988 \\
\hline PMF, unregulated & 1550 & McCann and Boissonnade 1988 \\
\hline $\begin{array}{l}\text { Peak discharges from years 1948, 1960, 1997, } \\
1967\end{array}$ & $690,547,455,206$ & McCann and Boissonnade 1988 \\
\hline
\end{tabular}

\subsection{Results}

The MASS1 output of water surface elevation at the center of each river channel cross section for each of the three steady-state flood simulations was converted from NGVD29 to North American Vertical Datum of 1988 and then georeferenced in Washington State Plane coordinates (Figure 3.1). At each cross section, the simulated water surface was assumed to extend out in the direction perpendicular to the river course. The resulting water surface elevation map was compared to a 3-m resolution digital elevation model for the Hanford Site, and flooding was assumed to occur or potentially occur wherever the water surface was higher than ground surface. Areas not connected to the river by surface pathways but nevertheless lower than the water surface elevation were mapped as possible flooded areas. The highly permeable soils and sediments that compose the shallow subsurface in this part of the Hanford Site would very likely permit groundwater flow of riverine water to these low-lying areas. 
Maps showing the extent of the floodplains for the 100-year, 500-year, and Standard Project Floods (SPFs) are given in Figure 3.2-Figure 3.4. In the 100-year and 500-year cases, the water is mostly contained in the topographic trench that is the main river channel, and the difference in the flooded areas is relatively small. For the much larger SPF, the flooded area extends beyond the river channel in some places, particularly in the 100-F Area.

All of the MASS1 model results have been archived and are available for future reference.

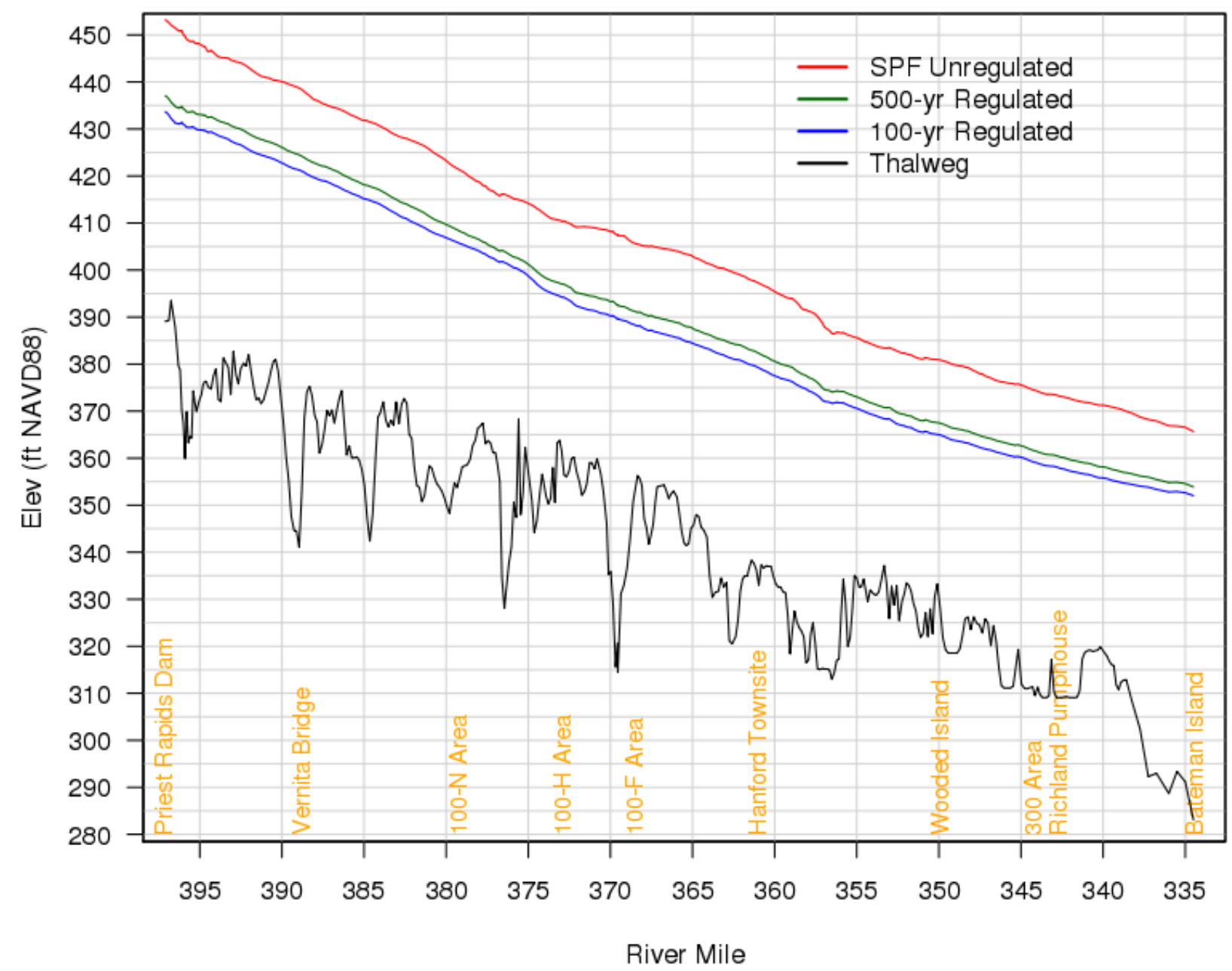

Figure 3.1. Hanford Reach water elevation profiles for three flood flows. 


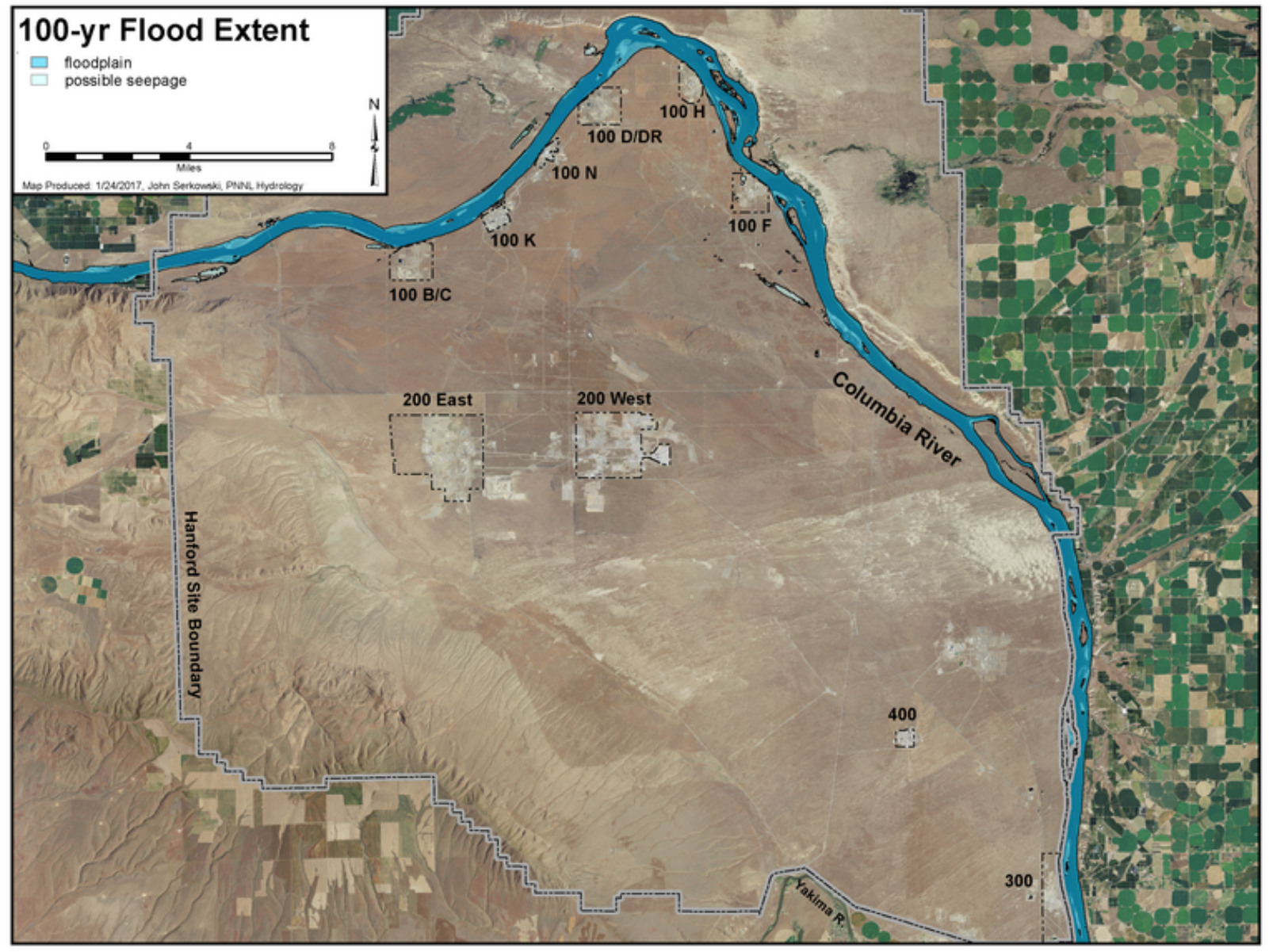

Figure 3.2. 100-year floodplain for the Hanford Reach. Columbia River discharge at Priest Rapids Dam set at $445 \mathrm{kcfs}$. 


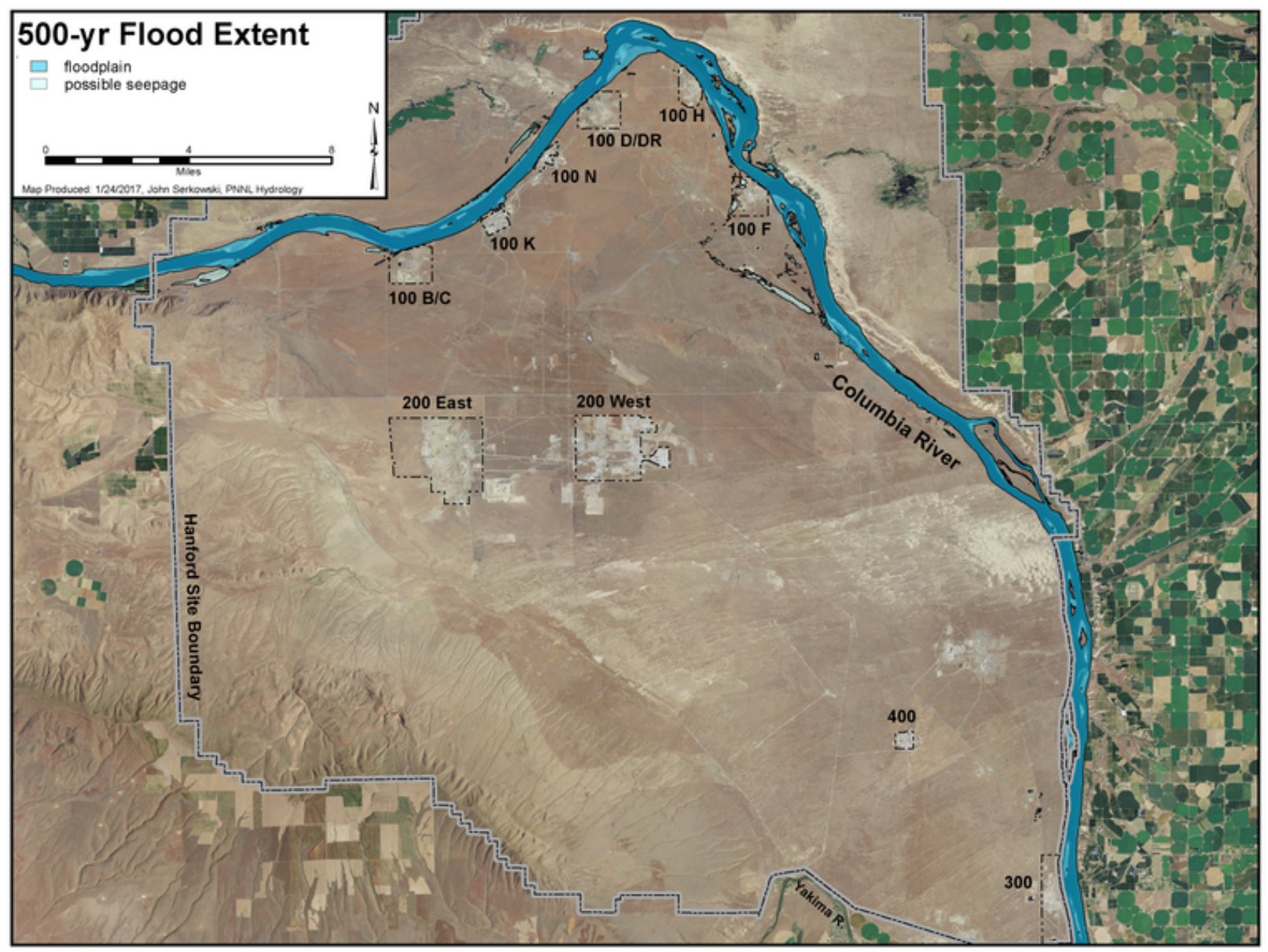

Figure 3.3. 500-year floodplain for the Hanford Reach. Columbia River discharge at Priest Rapids Dam set at $520 \mathrm{kcfs}$. 


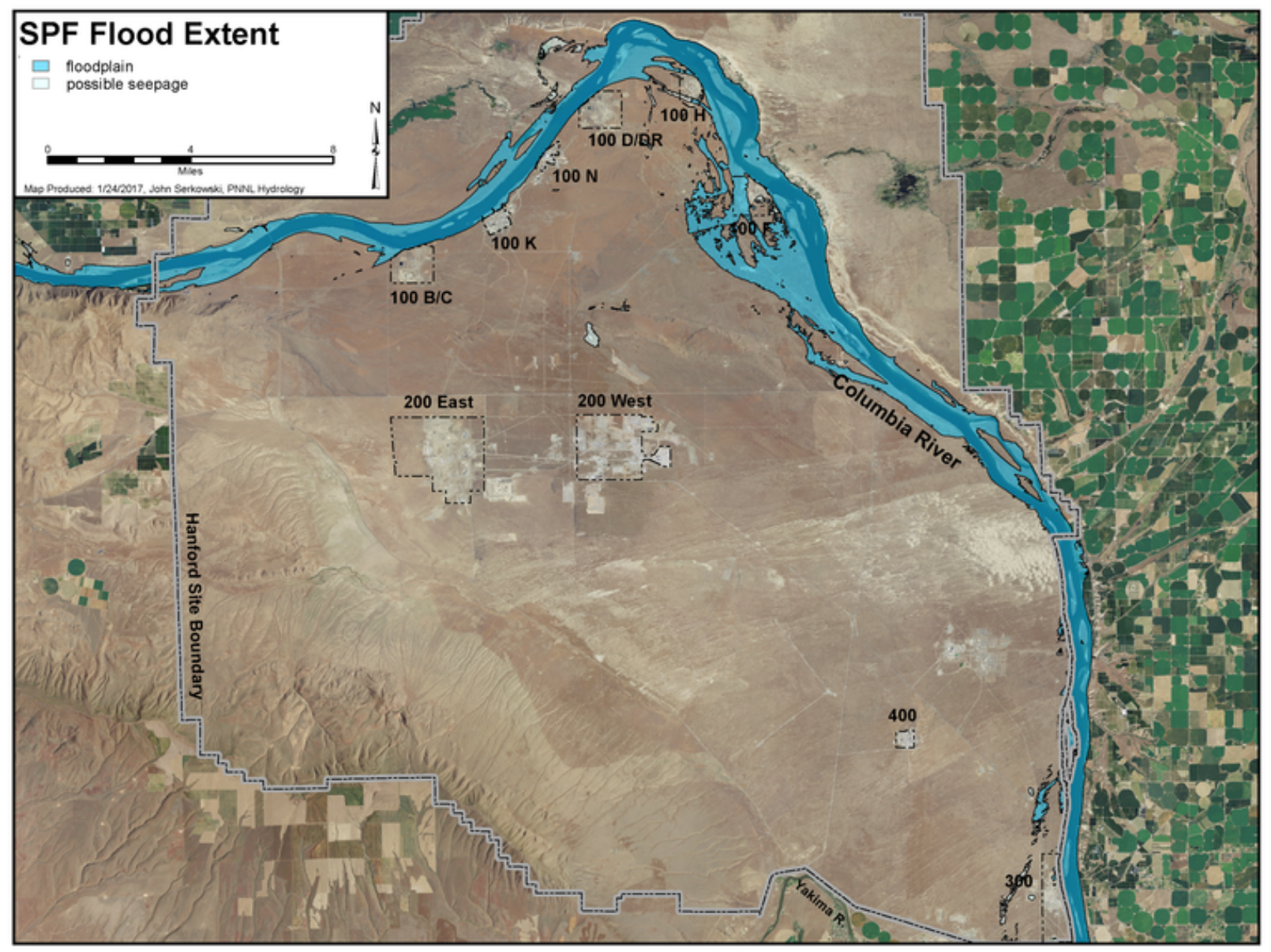

Figure 3.4. Standard Project Flood floodplain for the Hanford Reach. Columbia River discharge at Priest Rapids Dam set at 960 kcfs.

\subsection{Conclusion}

Floodplain maps show that for the 100-year and 500-year discharge levels, flooding is mainly confined to the primary river channel. The flooded area for the SPF extends out of the channel area in some places, particularly in the 100-F Area. All of the output from the simulations have been archived and are available for future investigations in the Hanford Reach. 


\subsection{References}

Coleman AM, DL Ward, KB Larson, and JW Lettrick. 2010. Development of a High-Resolution Bathymetry Dataset for the Columbia River through the Hanford Reach. PNNL-19878, Pacific Northwest National Laboratory, Richland, Washington.

Duncan JP. 2007. Hanford Site National Environmental Policy Act (NEPA) Characterization. PNNL6415 Rev. 18. Pacific Northwest National Laboratory, Richland, Washington.

Executive Order. 1977. Executive Order 11988. "Floodplain Management.” The White House, 5/24/1977.

Executive Order. 2015. Executive Order 13690. "Establishing a Federal Flood Risk Management Standard and a Process for Further Soliciting and Considering Stakeholder Input." The White House, $1 / 30 / 2015$.

FEMA (Federal Emergency Management Agency). 2015. "Guidelines for Implementing Executive Order 11988, Floodplain Management, and Executive Order 13690, Establishing a Federal Flood Risk Management Standard and a Process for Further Soliciting and Considering Stakeholder Input.” Washington, D.C.

McCann MW and AC Boissonnade. 1988. Probabilistic Flood Hazard Assessment for the N-reactor, Hanford, Washington. UCRL-21069, Lawrence Livermore National Laboratory, Livermore, California.

McMichael, GA, CJ Murray, DR Geist, WA Perkins, MC Richmond, and A Coleman. 2006. Fluctuating Flows and Chinook Salmon: A Review of Previous Work Relevant to the Hanford Reach of the Columbia River. PNWD-3656, Battelle-Pacific Northwest Division, Richland, Washington.

Niehus SE, WA Perkins, and MC Richmond. 2014. Simulation of Columbia River Hydrodynamics and Water Temperature from 1917 through 2011 in the Hanford Reach. PNWD-3278, prepared for Grant County Public Utility District No. 2, by Battelle-Pacific Northwest Division, Richland, Washington. (Limited distribution)

Perkins WA and MC Richmond. 2001. Long-Term, One-Dimensional Simulation of Lower Snake River Temperatures for Current and Unimpounded Conditions. PNNL-13443, Pacific Northwest National Laboratory, Richland, Washington.

Perkins WA, MC Richmond, CL Rakowski, A Coleman, and GR Guensch. 2002. Effects of Wanapum and Priest Rapids Impoundments on Columbia River Temperature. PNWD-3269, prepared for Grant County Public Utility District No. 2, by Battelle-Pacific Northwest Division, Richland, Washington. (Limited distribution).

Richmond MC and WA Perkins. 2009. Efficient calculation of dewatered and entrapped areas using hydrodynamic modeling and GIS. Environmental Modeling \& Software 24(12):1447-1456. doi:10.1016/j.envsoft.2009.06.001.

Richmond MC, WA Perkins, and Y Chien. 2000. Numerical Model Analysis of System-Wide Dissolved Gas Abatement Alternatives - Final Report. PNWD-3245, Battelle-Pacific Northwest Division, Richland, Washington. 
Tallman AM. 1996. Natural Phenomena Hazards, Hanford Site, South-Central Washington. WHC-SDGN-ER-501, Rev. 0., Westinghouse Hanford Company, Richland, Washington.

Teasdale GN, B Moran, Y Seda-Sanabria, JW Hunter. 2009. Flood Modeling for the 2009 Dams Sector Exercise Series. Unpublished report. U.S. Army Corps of Engineers, Walla Walla District, Walla Walla, Washington.

USACE (U.S. Army Corps of Engineers). 1989. Water Control Manual for McNary Lock and Dam, Columbia River, Oregon and Washington. USACE Walla Walla District, Walla Walla, Washington.

USACE (U.S. Army Corps of Engineers). 2003. Columbia River Treaty Flood Control Operating Plan. USACE Hydrologic Engineering Branch, Water Management Division, Portland, Oregon.

USACE (U.S. Army Corps of Engineers). 2013. "McNary Lock and Dam Frequency Curves,” Plate 9-4, Army Corps of Engineers Walla Walla District, April 2013.

Waichler SR, WA Perkins, and MC Richmond. 2005. Hydrodynamic Simulation of the Columbia River, Hanford Reach, 1940-2004. PNNL-15226, Pacific Northwest National Laboratory, Richland, Washington. 


\section{Appendix A}

\section{Estimated Peak Flow Rates for the Columbia River Near the}

Hanford Reach 


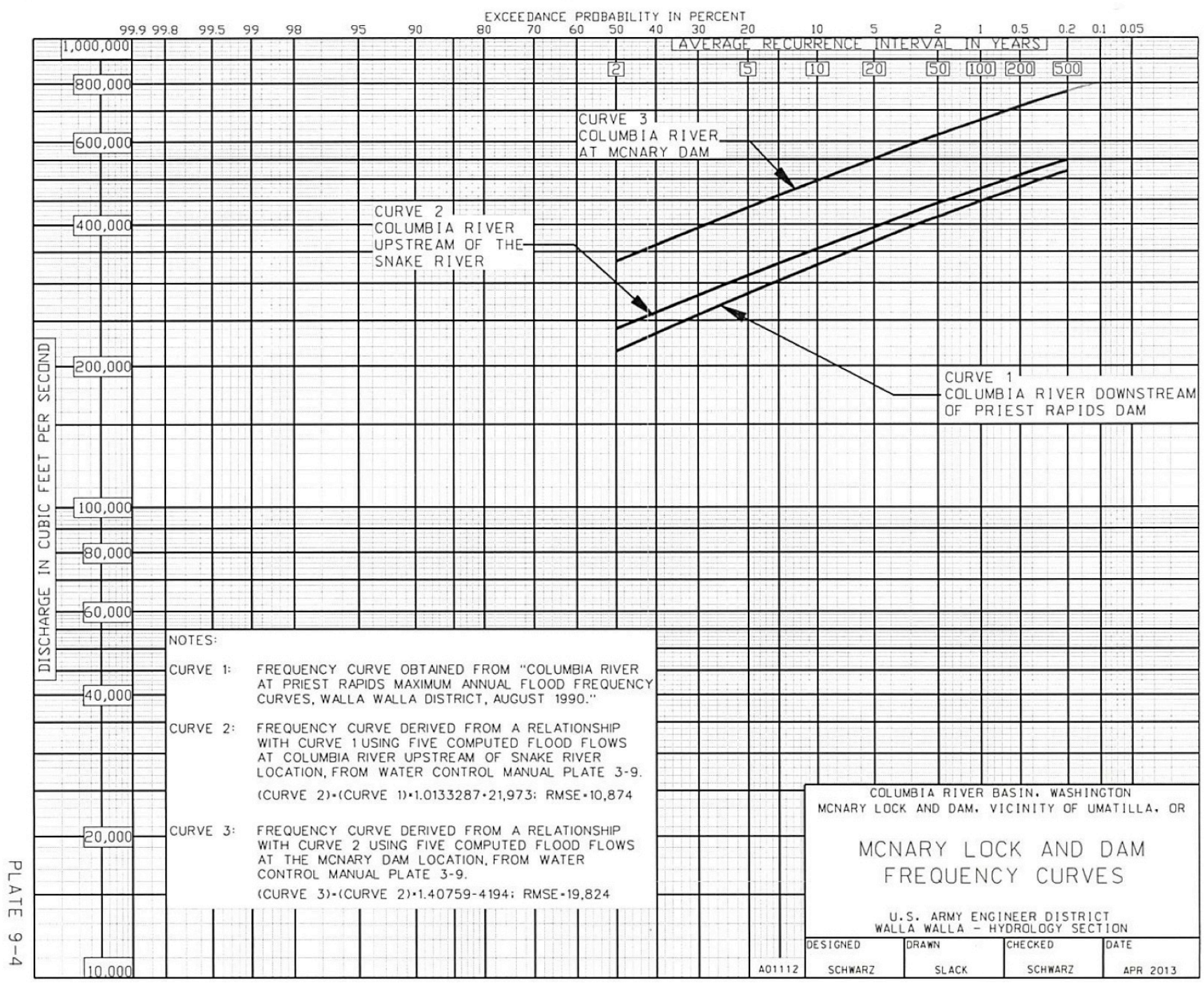

Figure A.1. Discharge rates (cfs) for the Columbia River vs. probability of occurrence at three locations. Information provided by US Army Corps of Engineers, Walla Walla District. 
Appendix B

Goodness-of-Fit Statistics Used in Calibration and Validation 


\section{Appendix B}

\section{Goodness-of-Fit Statistics Used in Calibration and Validation}

Mean absolute error (MAE) and Bias (B) were the primary goodness-of-fit measures used in calibration of MASS1. These and other goodness-of-fit statistics defined below were also used to evaluate model output in all years with data. Bias $B$ is defined as the ratio of predicted (simulated) mean to observed mean

MAE is defined as

$$
\mathrm{MAE}=\frac{1}{N} \sum_{i=1}^{N}\left|P_{i}-O_{i}\right|
$$

where

$$
\begin{aligned}
N & =\text { number of timesteps } \\
P & =\text { predictions } \\
O & =\text { observations }
\end{aligned}
$$

Bias is defined as

$$
B=\frac{1}{N} \sum_{i=1}^{N} P_{i}-O_{i}
$$




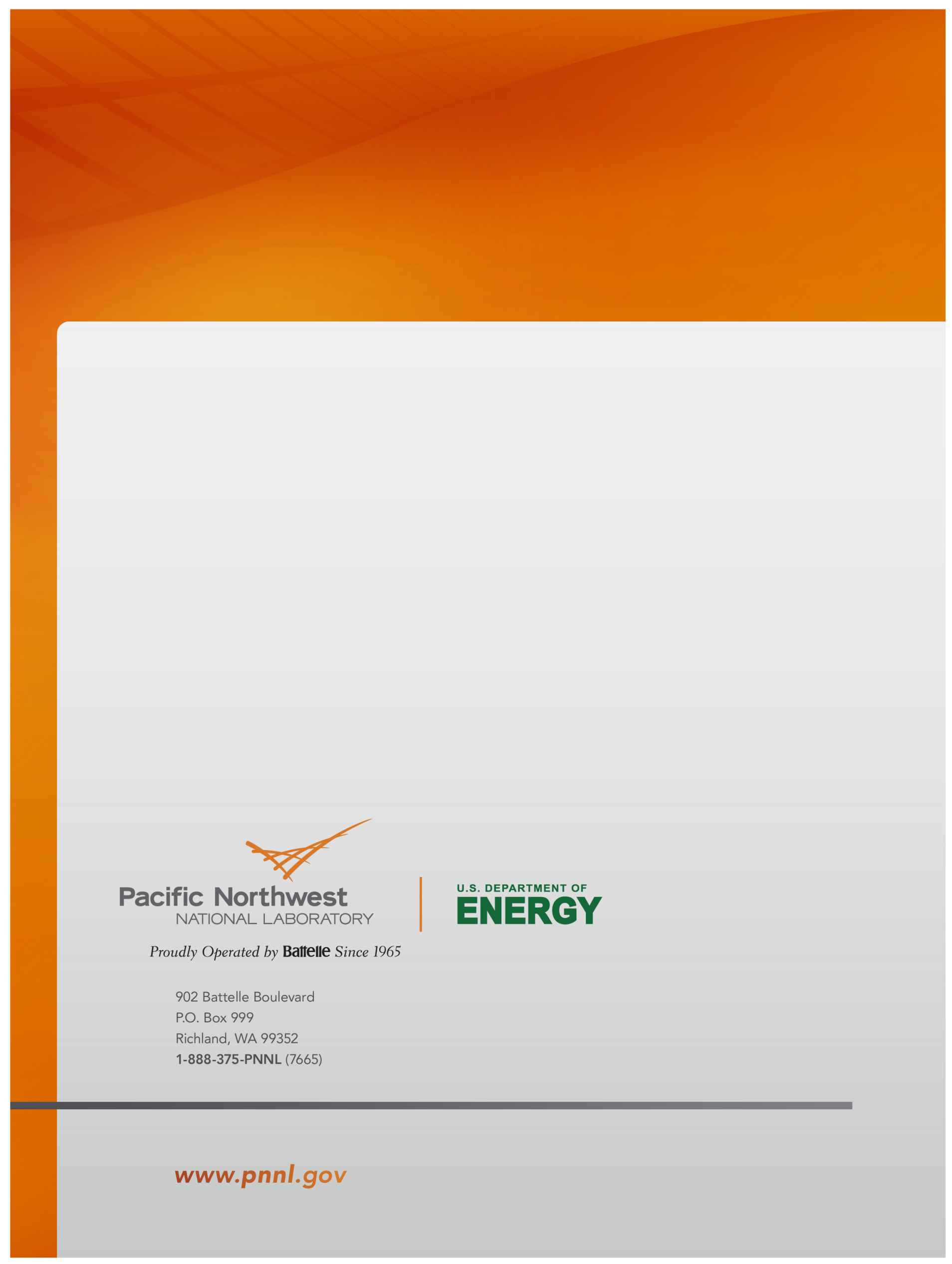

